\title{
Attitude and Intention to Buy Vietgap Vegetables of Inhabitants at Ho Chi Minh City, Vietnam
}

\author{
Ha Nam Khanh Giao \\ The Faculty of Air Transport, Vietnam Aviation Academy, Ho Chi Minh, Vietnam
}

Email address:

khanhgiaohn@yahoo.com

\section{To cite this article:}

Ha Nam Khanh Giao. Attitude and Intention to Buy Vietgap Vegetables of Inhabitants at Ho Chi Minh City, Vietnam. International Journal of Agricultural Economics. Vol. 4, No. 3, 2019, pp. 125-134. doi: 10.11648/j.ijae.20190403.16

Received: January 31, 2019; Accepted: May 29, 2019; Published: June 11, 2019

\begin{abstract}
The research aims at analyzing how the attitude factors affect the intention to buy VietGAP vegetables in Ho Chi Minh city, Vietnam (HCMC), by intervewing 633 inhabitants. The method of Cronbach's Alpha analysis, EFA analysis, CFA analysis and structural equation modelling (SEM) were used with the SPSS and AMOS programs. The result shows that there are 04 attitude factors affects on the intention to buy VietGAP vegetables in HCMC decreasingly: (1) Vegetables safety, (2) Belief, (3) Health concern, (4) Subjective norm. The research also suggests some solutions to the VietGAP vegetable producers to enhance the selling capability.
\end{abstract}

Keywords: VietGAP Food, Consumer Behavior, Ho Chi Minh City, Structural Equation Modelling, Purchase Intention

\section{Overview}

In Vietnam in general and HCMC in particular, production and supply of safe food - in particular safe vegetables - are following the process and safety standards have been Vietnamese government's concern. (Decision No. 379/QD of the Ministry of Agriculture and the Ministry of Science and Technology on the promulgation of Good Agricultural Practices for safe vegetables and fruits, 2008) In HCMC, Decision No. 3331/QD-People's Committee of HCMC dated July $04^{\text {th }}$ 2011 approved the program with the aim of the development of safe vegetables in the city in the period between 2011 and 2015. However, the results are still limited, consumers still do not have a strong belief in the safety of vegetables, this item is still neglected in the markets and the primary markets, mainly consumed in the supermarket system.

This topic was implemented to help vegetable traders understand the attitude and intentions of consumers on this commodity in order to propose measures to improve the purchasing power of the citizens so that it can help improve the quality of life and the efficiency of safe vegetable production and trading in HCMC.

\section{Theoretical Structure and Research Model}

\subsection{VietGAP Vegetables}

Prior to 2008, before VietGap standard was promulgated, the Ministry of Agriculture and Rural Development (MARD) had introduced the concept of safe vegetables: Fresh and clean vegetable products (including leaves, flowers, fruits) of the same quality as its characteristics with the level of toxic chemicals and the level of infection of harmful organisms are all below the permitted level, ensuring the safety of consumers and the environment, are considered the vegetables ensuringfood safety and hygieneshortened-called as "safe vegetables" (Decision No. 67/1998/QD of the Ministry of Agriculture and the Ministry of Science and Technology dated April 28 ${ }^{\text {th }} 1998$ ).

Since 2008, the concept of safe vegetables has been institutionalized in Article 2 - "Regulations on safe vegetable, fruit and tea production and trading management" (Decision 99/2008/QD dated October $15^{\text {th }} 2008$ of MARD): Safe vegetables and fruits are fresh vegetables and fruits produced and preliminarily processed in accordance with the regulations on food safety and hygiene inVietGAP (Process of good-agricultural production practice for safe vegetables 
and fruits in Vietnam) or other GAP standards equivalent to VietGAP and typical samples acquiring food hygiene and safety criteria.

\subsection{The Correlation Between Attitude and Purchase Intention}

Personal belief is the source of attitudes [2]. Attitude is the positive or negative feeling of the individual about performing a certain behavior. Attitude describes the extent to which an individual judges the outcome of an act as positive or negative [10]. This study uses the notion of: Attitude is the positive or negative feelings of the individual about performing a certain behavior.

The intention of action is defined by Ajzen as human action guided by the consideration of three factors of belief in behavior, belief in norms and belief in control [3]. The stronger these beliefs are, the greater the intention of human activity is.

Theory of planned behavior [2] is the extension of the theory of reasoned action (TRA) [7]. Identification is the key to behavior, it is an indicator of how much people will try, or how much effort will be devoted to implementing a particular behavior. In this theory, the intention of behavior is influenced by three factors: (1) attitude towards behavior, (2) subjective norms, and (3) perceived behavioral control.

The correlation between attitude and intention has been investigated by several authors and found to be strongly correlated. Behavioral attitude, subjective norms, and perceived behavioral control lead to intentional behavior [1]. As a rule, the better the attitude is, the more likely someone is to make a purchase. Nguyen also shows that there is a high correlation between attitude towards organic food and purchase intention [14]; The results also coincide with the results of previous studies [10, 12, 13, 17, 18].

The study conducted by Nguyen in Hanoi and HCMC showed the influence of environmental factors, perceptions on values, attention to health, understanding the food safety and subjective norms are clearly linked to the intention of purchasing safe food from consumers in both the South and the North [14]. Research by Nguyen conducted in HCMC showed that the main factors affecting the intention to buy safe vegetables of consumers are the price and belief in the product [15]. Pham found that three factors were positively correlated with the intention to buy safe vegetables: (1) safe vegetables and distributors' belief, (2) health and environmental concern, (3) opinion of the reference group [16].

Research by Dickieson suggests that consumers' behavior in the UK is influenced by factors such as health concern, perceived quality, health security concern, beliefs and higher prices for safe food products [6]. The study by Shaharudin shows the factors influencing the intention to purchase safe food in Malaysia include perceived value and health concern
[18]. Tarkiainen point out that consumers' intention to buy organic food can be predicted by their attitudes; moreover, they can be predicted by subjective norm and behavioral intention can obviously be used to predict purchase behavior [19]. Voon has resulted in significant subjective attitudes and standards that significantly influence willingness to pay while controlling behavior is negligible; Attitudes also affect subjective norms and behavioral control [20]. Avitia showed that attitudes toward organic food can be explained by the perception of risk and belief in the market and organization, knowledge and concern of ealth and the environment are mediated by the beliefs in the market and the perception of risks towards attitudes towards organic food and attitudes towards organic food, prices and subjective norms explain purchase intention [5].

\subsection{Research Hypotheses and Proposed Research Model}

Based on theory of planned behavior [2] and previous studies, the author proposes a model of research shown in Figure 1, along with theoretical hypotheses as below:

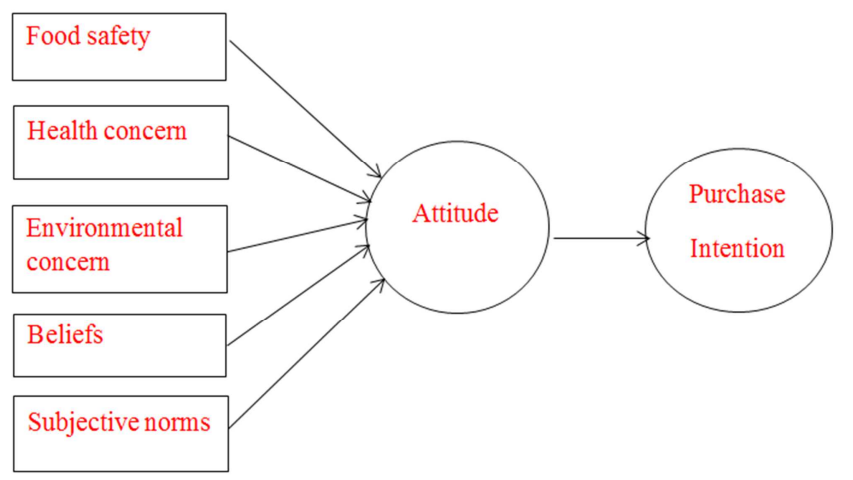

Figure 1. The proposed research model.

(Source: proposed by the author).

$\mathrm{H}_{1}$ : Health concern affects the purchase attitude of VietGAP.

$\mathrm{H}_{2}$ : Environmental concern affects the purchase attitude of VietGAP.

$\mathrm{H}_{3}$ : The beliefs affect the purchase attitude of VietGAP.

$\mathrm{H}_{4}$ : Food safety affects the purchase attitude of VietGAP.

$\mathrm{H}_{5}$ : Subjective norms affect the purchase attitude of VietGAP.

$\mathrm{H}_{6}$ : The purchase attitude of VietGAP vegetables affects the purchase intention of VietGAP vegetables of the consumers.

\section{Results and Discussion}

\subsection{Sample Description Statistics}

The survey respondents were the consumers whose ages are between 18 and 60, have never used VietGAP or used but did not care about using vegetables with this standard before. The number of direct survey questionnaires was 650, after the screening and elimination of invalid ones, the remaining $633(98 \%)$ was used in the official analysis.

Table 1. Characteristics of survey respondents.

\begin{tabular}{llll}
\hline Characteristics & & Frequency & Percent (\%) \\
\hline \multirow{2}{*}{ Gender } & Female & 433 & 68.4 \\
& Male & 200 & 31.6 \\
\hline
\end{tabular}




\begin{tabular}{llll}
\hline Characteristics & Frequency & Percent (\%) \\
\hline \multirow{3}{*}{ Age } & $18-25$ & 243 & 38.4 \\
& $26-35$ & 202 & 31.9 \\
& $36-45$ & 110 & 17.4 \\
& $>45$ & 78 & 12.3 \\
Income (Vietnamese Dong- VND) & $5-10$ million & 186 & 29.4 \\
& $<-5$ million & 282 & 44.5 \\
& $10-15$ million & 130 & 20.5 \\
\hline
\end{tabular}

(Source: Survey results of the author).

\subsection{Rating Scale with Cronbach's Alpha Reliability}

The Cronbach's Alpha results of the scale items in Table 2 showed that all the scales had got Cronbach's Alpha greater than 0.6. At the same time, the total - item correlation was greater than 0.3 8] (Hair, 1999). Thus, the items of the scale satisfied the required reliability, which were good scales and were sufficient enough for EFA analysis.

Table 2. The Cronbach's Alpha results of the scales.

\begin{tabular}{llllll}
\hline No. & Scale & & No. of items & Cronbach's Alpha & Cronbach's Alpha if Item Deleted \\
\hline 1 & Health concern & SK & 4 & .841 & .670 \\
2 & Environmental concern & MT & 3 & .825 & .670 \\
3 & Beliefs & TT & 4 & .894 & .744 \\
4 & Subjective norms & CCQ & 3 & .804 & .630 \\
5 & Food hygiene & AT & 4 & .868 & .710 \\
6 & Attitude & TD & 4 & .894 & .742 \\
7 & Purchase Intention & YD & 3 & .835 & .686 \\
\hline
\end{tabular}

(Source: measured by the author).

\subsection{Exploratory Factor Analysis (EFA)}

The KMO test showed that KMO was quite high $(0.888>\mathrm{KMO}>0.5)$, Barlett's test had sig $=0.000<0.05$ showed an appropriate analysis of EFA and observed variables with linear correlation calculated with representative elements.

Based on the results of the EFA of the independent variables, six factors were extracted at Eigenvalues $=1.266(>1)$. The total variance was $73.661 \%$ satisfactory $(>50 \%)$, meaning that $73.661 \%$ of the variation of the factors was explained by the observed variables [8]. The extracted elements were credible and worthwhile (Table 3).

Table 3. The results of the EFA analysis.

\begin{tabular}{|c|c|c|c|c|c|c|}
\hline \multirow{2}{*}{ Items } & \multicolumn{6}{|c|}{ Factors } \\
\hline & 1 & 2 & 3 & 4 & 5 & 6 \\
\hline TT2 & .862 & & & & & \\
\hline TT4 & .804 & & & & & \\
\hline TT3 & .803 & & & & & \\
\hline TT1 & .788 & & & & & \\
\hline AT4 & & .802 & & & & \\
\hline AT2 & & .800 & & & & \\
\hline AT3 & & .782 & & & & \\
\hline AT1 & & .768 & & & & \\
\hline TD1 & & & .848 & & & \\
\hline TD3 & & & .813 & & & \\
\hline TD4 & & & .809 & & & \\
\hline TD2 & & & .777 & & & \\
\hline SK4 & & & & .757 & & \\
\hline SK3 & & & & .755 & & \\
\hline SK2 & & & & .753 & & \\
\hline SK1 & & & & .746 & & \\
\hline YD1 & & & & & .810 & \\
\hline YD3 & & & & & .786 & \\
\hline YD2 & & & & & .781 & \\
\hline CCQ1 & & & & & .791 & \\
\hline $\mathrm{CCQ} 3$ & & & & & .766 & \\
\hline
\end{tabular}




\begin{tabular}{llllll}
\hline \multirow{2}{*}{ Items } & Factors & & & \\
\cline { 2 - 5 } & $\mathbf{1}$ & $\mathbf{2}$ & $\mathbf{3}$ & $\mathbf{4}$ & $\mathbf{5}$ \\
\hline CCQ2 & & & .712 & $\mathbf{6}$ \\
MT1 & & & .780 & .780 \\
MT2 & & & .765 \\
MT3 & & & \\
\hline
\end{tabular}

(Source: measured by the author).

Results of the dependent variable analysis with 3 observed variables, $\mathrm{KMO}=.801$, and Barlett's test with $\mathrm{Sig}=0.000<$ 0.5 , Average Variance Extracted $=62.084 \%$ and variables had factor loading greater than 0.5 [8]. Thus, the purchase intention of VietGAP vegetables includes 3 variables.

\subsection{Mesuring Scale by Confirmatory Factor Analysis (CFA)}

The saturated model is validated to measure the distinction among elements in the research model. The CFA results showed that the saturated model had 254 degrees of freedom.
The model had Chi-square $=378,030, \mathrm{p}=0.000(<0.05)$. The indicators $\mathrm{CMIN} / \mathrm{df}=1.488(<2), \mathrm{GFI}=0.954, \mathrm{TLI}=$ $0.982, \mathrm{CFI}=0.985(>0.9), \mathrm{RMSEA}=0.028$ are satisfactory after being considered [4]. Therefore, it may be possible to confirm that this model was appropriate, and that there was no correlation between the measurement errors and that it achieved unidimesionality (Figure 2).

The above results also showed that the CFA values of the observed variables were 0.5 (lowest is $\lambda_{\mathrm{CCQ} 2}=0.73$ ) and $\mathrm{p}=$ 0.000 . Thus, it is possible to confirm the convergent validity of the scale used in the research model.

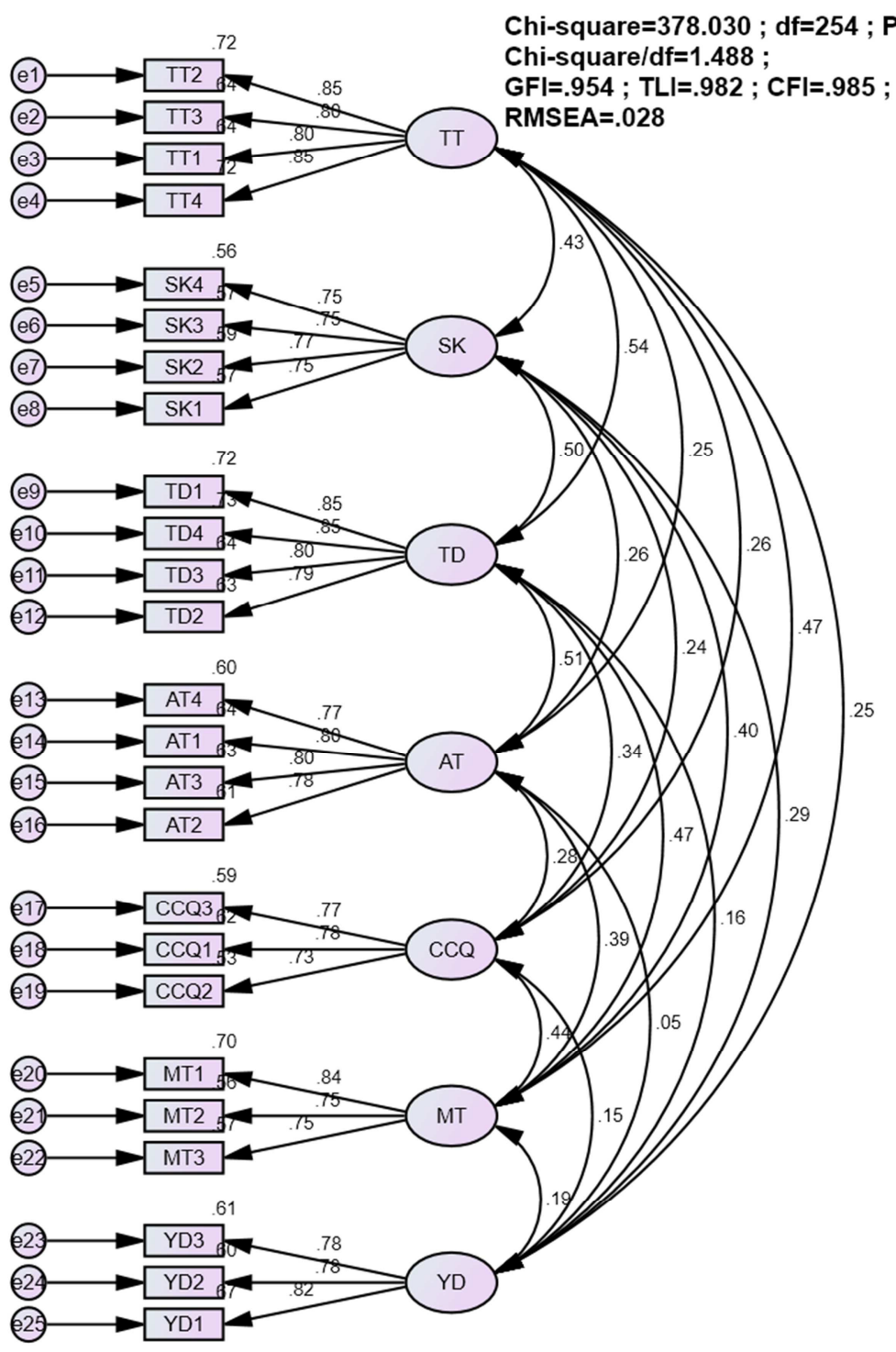

(Source: measured by the author).

Figure 2. CFA Result in saturated model (standardized). 
Table 4. The result of distinctive values in saturated model.

\begin{tabular}{|c|c|c|c|c|}
\hline The relations & $\mathbf{r}$ & SE & $\mathbf{C R}$ & p-value \\
\hline Beliefs $\longleftarrow \rightarrow$ Health concern & .434 & .036 & 15.782 & 0.000 \\
\hline Beliefs $\longleftarrow \longrightarrow$ Attitude & .539 & .034 & 13.748 & 0.000 \\
\hline Beliefs $\longleftarrow \longrightarrow$ Food safety & .251 & .039 & 19.437 & 0.000 \\
\hline Beliefs $\longleftrightarrow \longrightarrow$ Subjective norms & .261 & .038 & 19.230 & 0.000 \\
\hline Beliefs $\longleftrightarrow \longrightarrow$ Environmental concern & .465 & .035 & 15.180 & 0.000 \\
\hline Beliefs $\longleftrightarrow \longrightarrow$ Purchase Intention & .247 & .039 & 19.520 & 0.000 \\
\hline Health concern $\longleftrightarrow$ Attitude & .501 & .034 & 14.484 & 0.000 \\
\hline Health concern $\longleftrightarrow$ Subjective norms & .245 & .039 & 19.562 & 0.000 \\
\hline Health concern $\longleftrightarrow \longrightarrow$ Environmental concern & .403 & .036 & 16.386 & 0.000 \\
\hline Health concern $\longleftrightarrow$ Purchase Intention & .291 & .038 & 18.615 & 0.000 \\
\hline Attitude $\longleftarrow \longrightarrow$ Food safety & .509 & .034 & 14.329 & 0.000 \\
\hline Attitude $\longleftrightarrow \longrightarrow$ Subjective norms & .342 & .037 & 17.589 & 0.000 \\
\hline Attitude $\longleftrightarrow \longrightarrow$ Environmental concern & .469 & .035 & 15.103 & 0.000 \\
\hline Attitude $\longleftarrow \longrightarrow$ Purchase Intention & .164 & .039 & 21.288 & 0.000 \\
\hline Food safety $\longleftrightarrow \longrightarrow$ Environmental concern & .390 & .037 & 16.641 & 0.000 \\
\hline Food safety $\longleftrightarrow \longrightarrow$ Purchase Intention & .046 & .040 & 23.990 & 0.000 \\
\hline Subjective norms $\longleftrightarrow \longrightarrow$ Environmental concern & .435 & .036 & 15.762 & 0.000 \\
\hline Subjective norms $\longleftrightarrow \longrightarrow$ Purchase Intention & .152 & .039 & 21.552 & 0.000 \\
\hline Environmental concern $\longleftrightarrow$ Purchase Intention & .193 & .039 & 20.660 & 0.000 \\
\hline
\end{tabular}

(Source: measured by the author).

The result of distinctive values of the concepts in saturated model is presented in Table 4. Accordingly, the correlation coefficient $r$ between each pair of variables was different from 1 and $\mathrm{p}=0.000(<0.05)$, concepts reached distinct values.

Table 5 showed that the Cronbach's Alpha coefficients were greater than 0.6 , the composite reliability of the factors wass greater than 0.5 and the Variance extracted was greater than $50 \%$, so that the factors' scale reached the essential reliability.

Table 5. Reliability and Variance extracted of the factors in the model.

\begin{tabular}{llll}
\hline Factors & $\begin{array}{l}\text { Observed } \\
\text { Variables (Items) }\end{array}$ & $\begin{array}{l}\text { Cronbach's } \\
\text { Alpha }\end{array}$ & $\begin{array}{l}\text { Variance } \\
\text { extracted }\end{array}$ \\
\hline Health concern & 4 & .841 & .570 \\
Environmental concern & 3 & .825 & .611 \\
Beliefs & 4 & .894 & .679 \\
Food safety & 4 & .868 & .621 \\
Subjective norms & 3 & .804 & .579 \\
Attitude & 4 & .894 & .680 \\
Purchase intention & 3 & .835 & .628 \\
\hline
\end{tabular}

(Source: measured by the author).

The confirmatory factor analysis with all indicators results suitable for the Multi-Sample Model, the scales satisfied the requirements to conduct SEM analysis.

\subsection{SEM Analysis}

The estimated results of the theoretical model (Figure 3) showed Chi-square $=417.129$, with 259 degrees of freedom, $\mathrm{p}=0.000, \chi^{2} / \mathrm{df}=1.611(<3)$ demonstrating a good model fit, $\mathrm{GFI}=0.950, \mathrm{TLI}=0.977, \mathrm{CFI}=0.980$ are $>0.9$, RMSEA $=0.031(<0.08)$, the model meets the widely accepted goodness of fit standards for the Multi-Sample confirmatory model indicating that the conceptual model satisfactory fits the data [4].
The results of the correlation analysis between the variables in the model showed that the MT variable (environmental concern) had $\mathrm{p}$-value $=0.137>0.05$ which did not affect attitude or reject the hypothesis $\mathrm{H}_{2}$, then the MT variable could have been removed from the analytical model.

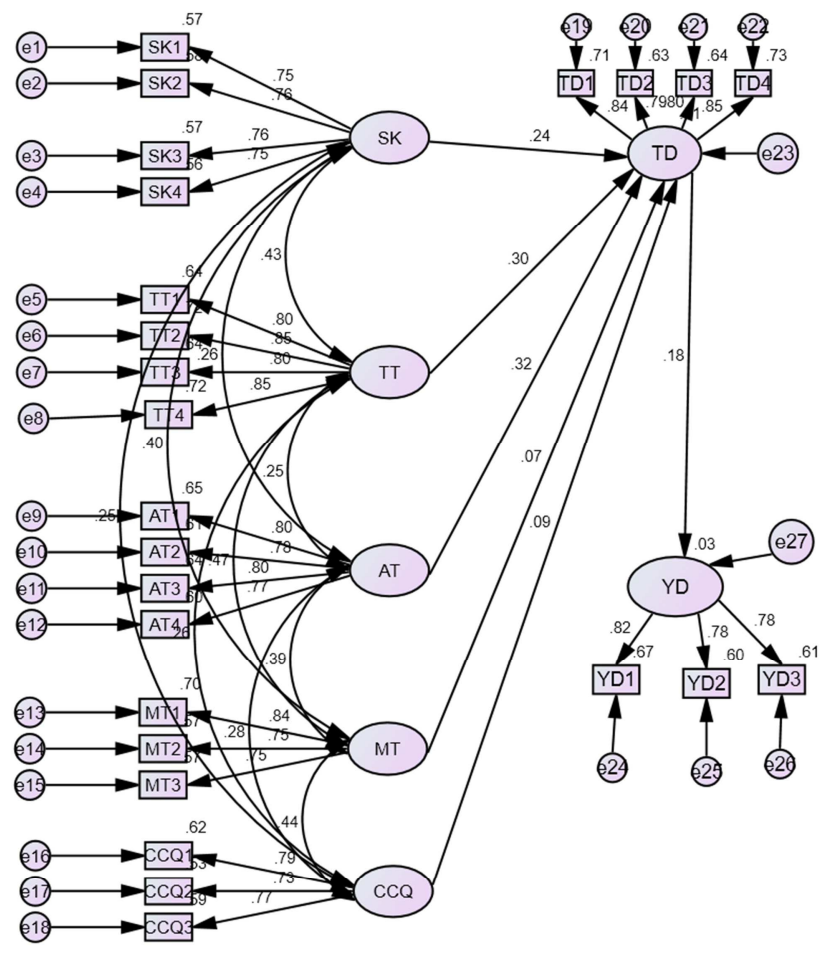

Chi-square=417.129; df=259; $P=.000$;

Chi-square/df $=1.611$;

$\mathrm{GFI}=.950 ; \mathrm{TLI}=.977 ; \mathrm{CFI}=.980$; RMSEA $=.031$

(Source: measured by the author).

Figure 3. The result of the $1^{\text {st }}$ SEM (standardized model). 
The results of SEM after removing MT variable from the analytical model are presented in Figure 4. The results of the regression coefficient estimation of relations are presented in Table 6, which shows that all the correlations amongst hypotheses were statistically significant (p-value $<0.05$ ). Thus, the results of the analysis is that the hypotheses $\mathrm{H}_{1}, \mathrm{H}_{3}$, $\mathrm{H}_{4}, \mathrm{H}_{5}, \mathrm{H}_{6}$ are supported.

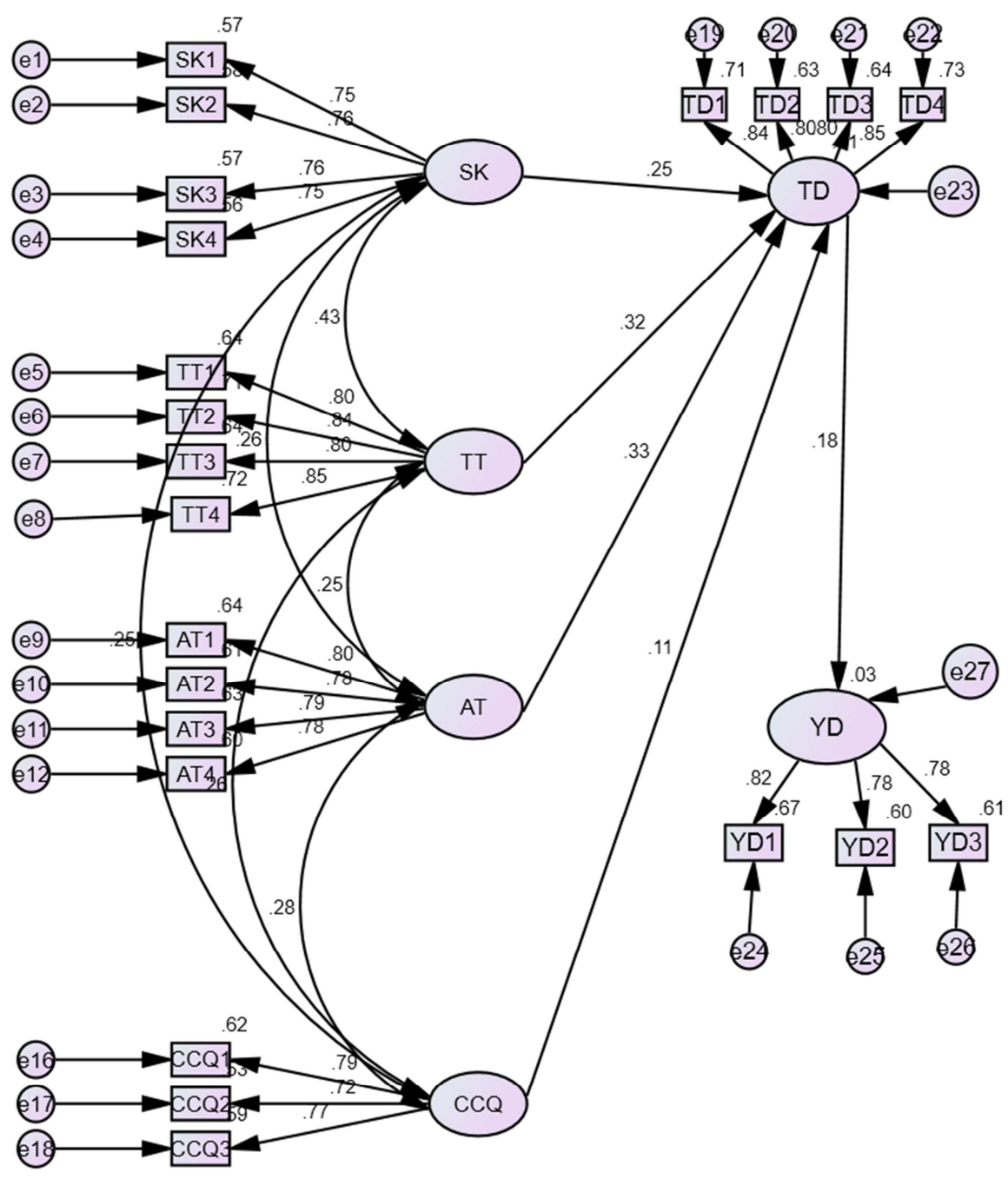

Chi-square=319.129; df=198; $P=.000$;

Chi-square/df $=1.612$;

$\mathrm{GFI}=.957 ; \mathrm{TLI}=.980 ; \mathrm{CFI}=.983$;

RMSEA $=.031$

(Source: measured by the author).

Figure 4. The result of the $2^{\text {nd }}$ SEM (standardized model)

The result shows that the food safety factor has a positive and direct impact on the highest purchase attitude of VietGAP vegetables $\left(\lambda_{\mathrm{AT}}=0.332\right)$, followed by beliefs $\left(\lambda_{\mathrm{TT}}=0.321\right)$, health concern $\left(\lambda_{\mathrm{SK}}=0.252\right)$ and finally the subjective norms $\left(\lambda_{\mathrm{CCQ}}\right.$ $=0.106)$. At the same time, the purchase attitude of VietGAP also positively and directly influenced the purchase intention of $\operatorname{VietGAP}\left(\lambda_{\mathrm{TD}}=0.183\right)$. This result is consistent with previous studies.

Table 6. Regression coefficient of the correlations in the model.

\begin{tabular}{llllll}
\hline Hypotheses & Correlations among variables & Estimated & S. E & C. R & p-value \\
\hline $\mathrm{H}_{1}$ & Health concern $\rightarrow$ Attitude & .221 & .037 & 5.941 & 0.000 \\
$\mathrm{H}_{3}$ & Beliefs $\rightarrow$ Attitude & .261 & .034 & 7.724 & 0.000 \\
$\mathrm{H}_{4}$ & Food safety $\rightarrow$ Attitude & .273 & .033 & 8.378 & 0.000 \\
$\mathrm{H}_{5}$ & Subjective norms $\rightarrow$ Attitude & .094 & .035 & 2.699 & 0.007 \\
$\mathrm{H}_{6}$ & Attitude $\rightarrow$ Purchase Intention & .158 & .039 & 4.003 & 0.000 \\
\hline
\end{tabular}

(Source: measured by the authors). 


\subsection{Bootstrap Test}

The repeated sample size of $\mathrm{N}=1000$ is used to test the sustainability of the theoretical model and evaluate the reliability of the estimates in the model. The results in Table 7 showed that the standard deviation (bias) is very small, and the critical value (C. R) is less than 2 indicating that in fact the estimated sample can be generalized. Thus, it can be concluded that the estimation model is sustainable and reliable.

Table 7. The estimated result of Bootstrap Test.

\begin{tabular}{lllll}
\hline Correlations & Estimated & Mean & Bias & SE-Bias \\
\hline Health concern $\rightarrow$ Attitude & .252 & .223 & .018 & .001 \\
Beliefs $\rightarrow$ Attitude & .321 & .260 & -.001 & .001 \\
Food safety $\rightarrow$ Attitude & .332 & .272 & .000 & .0 \\
Subjective norms $\rightarrow$ Attitude & .106 & .094 & .000 & .001 \\
Attitude $\rightarrow$ Purchase Intention & .183 & .159 & .001 & .001 \\
\hline
\end{tabular}

(Source: measured by the authors).

\subsection{Multi-group Model Validation}

The difference in chi-square test of the two models was 3.435 with 5 degrees of freedom, $p$-value $=0.633>0.05$, so there was no difference and the invariant model was appropriate or there was no difference in the effect of the factors of attitudes that affecting consumers' intention to purchase VietGAP vegetables in HCMC between the two sexes.

T-test by age groups showed that the Chi-square difference of the two models was 17.362 with 15 degrees of freedom, $\mathrm{p}$ value $=0.298>0.05$, so there was no difference in the effect of the factors influencing consumers' intention to buy VietGAP vegetables in HCMC among age groups.

The difference in Chi-square of the two models was 7.657 with 15 degrees of freedom, $p$-value $=0.937>0.05$, so there was no difference in the effect of the factors of attitudes affecting consumers' intention to purchase VietGAP vegetables in HCMC among different income groups.

\section{Conclusions and Recommendations}

\subsection{Conclusions}

Research uses qualitative and quantitative research methods to test scales model and official research model. The results showed that: (1) Cronbach's Alpha coefficients of the observed variables were satisfactory; (2) The results of the EFA satisfied the requirements, (3) all measurement concepts had reliability, distinctive validity and convergent validity, (4) research model test eliminated one hypothesis, and the rest 5 hypotheses were all accepted. $\mathrm{H}_{1}, \mathrm{H}_{3}, \mathrm{H}_{4}, \mathrm{H}_{5}, \mathrm{H}_{6}$, (5) The Boostrap test results showed a reliable model, (6) The results of multivariate analysis showed that there was no difference in the effect of the factors of attitude affecting consumers' purchase intention of VietGAP vegetables in HCMC between two sexes, between four age groups and between four income groups. Among the factors affecting the purchase attitude of VietGAP, food safety had the greatest impact $(\beta=0,332)$, followed by beliefs $(\beta=0.321)$, health concern $(\beta=0.252)$, and finally, the subjective norms $(\beta=$ $0,106)$, the purchase attitude of VietGAP vegetables positively and directly affected the purchase intention of
VietGAP's vegetables $(\beta=0.183)$.

\subsection{Managerial Implications}

\subsubsection{Food Safety}

This is a matter of great concern nowadays, according to the survey results consumers will intend to buy VietGAP vegetables, they believe that this product is safer than conventional products. And this is also the strongest factor that influences the purchase attitude towards VietGAP vegetables of consumers.

Table 8. Mean of observed food safety variables.

\begin{tabular}{ll}
\hline Variables & Mean \\
\hline VietGAP vegetables are safer & 3.6382 \\
VietGAP vegetables do not contain GM ingredients & 3.6793 \\
VietGAP vegetables reduce the risk of food poisoning & 3.6303 \\
VietGAP vegetables have the concentration of chemicals, & 3.6572 \\
allowed micro-level which is not harmful to human health & \\
\hline
\end{tabular}

However, the two variables "VietGAP vegetables reduce the risk of food poisoning", "VietGAP vegetables are safer" had the lowest means at 3.6303 and 3.6382, respectively, indicate that consumers still had doubts about food safety. Businesses need to ensure that the production of this product is in line with well-established standards that ensure food safety before being sold at the stores. Building a safe value chain is a great way to better manage this. In addition, booths displaying vegetable products sold in supermarkets and shops must meet the hygiene and safety standards of the Ministry of Health, supermarkets / stores must have experts on vegetables, technical requirements on storage (temperature, preliminary processing...).

To help consumers know the safety features of VietGAP vegetables, communication activities, advertising of these types of products are indispensable as well as stamps of origin, regulation of chemical content and micro residual birth.

In addition, government agencies are also responsible for ensuring food safety by regularly checking the production process of VietGAP vegetables by the farmers, taking samples to analyze, checking the concentration of fertilizers, ensuring micro-organisms must be at the permitted level before being sold to consumers, regularly checking food 
hygiene and safety at the shops selling these types of products.

\subsubsection{Beliefs}

That the variable "I believe that local VietGAP producers are following farming standards" which had the lowest mean (3.8215) indicates that consumers did not trust VietGAP produced under this standard. They were suspicious of the farming process, mainly irresponsible use of pesticides, herbicides and growth substances which involves incorrect dosage as well as wait-time prior to consumption. The businesses of these types of products should be honest about the production process of VietGAP. At the shops selling this product, enterprises can introduce to the consumers the table showing the levels of chemicals, microorganisms... but still ensure the health of consumers, In addition, businesses can get stamps on the levels of plant medicines, chemical fertilizers, microorganisms, etc. and cooperate with the farmers to control the cultivation process as well as to take care of this product in accordance with the VietGAP standards set by the competent authorities. Relevant authorities should be responsible for detailing the areas of VietGAP's vegetable production plan to the consumers, increasing the trustworthiness of the quality stamp affixed to the product packaging $($ mean $=3.8436)$.

Table 9. Mean of observed belief variables.

\begin{tabular}{ll}
\hline Variables & Mean \\
\hline $\begin{array}{l}\text { I believe VietGAP distributors are honest about its origin } \\
\text { I believe that local VietGAP producers are following }\end{array}$ & 3.8641 \\
$\begin{array}{l}\text { farming standards } \\
\text { I believe the logo of the authorized agency to certify }\end{array}$ & 3.8215 \\
$\begin{array}{l}\text { vegetables produced by VietGAP standards } \\
\text { I trust the information of quality stamp of VietGAP }\end{array}$ & 3.8420 \\
\hline
\end{tabular}

To increase the trust of the logo of the authorities that verify the VietGAP standard vegetable production (mean = 3.8420), the VietGAP logo on the package must be issued by the organization that is authorized to issue this certificate nationwide. At present, there are 6 VietGAP certification centers: QUATEST 3; Quality Center for Agriculture, Forestry and Fishery of Region 4; Center for agricultural economic restructuring and consultancy in HCM; FCC Inspection and Disinfection Joint Stock Company; Coffee Inspection and Export Joint Stock Company (CAFECONTROL); Southern Representative Office of Globalcert Joint Stock Company. In particular, the Center for Agricultural Advisory and Assistance HCMC grants free VietGAP certification for facilities in HoChiMinh city under the policy of encouragement and support of the People's Committee of HoChiMinh city.

"I believe VietGAP distributors are honest about its origin" has an average value of 3.8641. To ensure the origin of VietGAP vegetables, enterprises have to stamp the trace origin. In addition, the logo affixed to the product should be certified by the authorities. This will increase the trust of consumers in current and future VietGAP vegetables.

Building a strong brand name for VietGAP producers and traders is also an issue that needs to be implemented. At present, there are not many strong brands known for their reputation for safe food production and trading. If this is done, the trust of consumers will be improved and hence the buying attitude of VietGAP will be higher, leading to higher VietGAP purchase intention. To build up the brand, producers must combine with the distributors of VietGAP vegetables to organize agricultural markets to promote products, create opportunities for exchanges among consumers, producers, and distributors.

\subsubsection{Health Consciousness}

Health consciousness of consumers will form the purchase attitude of VietGAP vegetables and then lead to the purchase intention.

Table 10. Mean of observed health consciousness variables.

\begin{tabular}{ll}
\hline Variables & Mean \\
\hline I choose VietGAP vegetables to ensure health & 3.7346 \\
I think of myself as a health conscious consumer & 3.7583 \\
I often think about health issues & 3.7551 \\
I am interested in the type and amount of nutrition in the & 3.7946 \\
\hline
\end{tabular}

The observed variable "I choose VietGAP vegetables to ensure health" had the lowest mean (3.7346), indicating that consumers are aware that using VietGAP vegetables to ensure an abundant health is not highly concerned. To make consumers be more aware that VietGAP vegetables will benefit their health, VietGAP vegetables businesses should carry out activities or health programs at fairs or through mass media. At there, businesses will give nutrition advice on VietGAP vegetables as well as the benefits of using this product instead of ones of unknown origin, quality to improve consumers' health.

With the current widespread information on dangers of food and such health-related activities and programs, more consumers will be more concerned about the health when purchasing foods as well as the nutrition in the foods, from that, consumers themselves will become aware that they are health conscious consumers

Variable "I often think about health issues" has the third highest mean (mean $=3.7551)$. The majority of consumers buying vegetables at markets have relatively low income $(<5$ million to 10 million $\mathrm{VND} /$ month), so the health consciousness is limited when choosing food. Therefore, agencies, organizations, local leaders should pay much more attention to the fact that if it is possible or not to raise the citizens' income so as to help consumers pay more concern about health issues.

\subsubsection{Subjective Norms}

This study also indicates that subjective norms are one of the factors contributing to the buying behavior of VietGAP which leads to the intention to buy VietGAP. Subjective norms are the realization of how to conform to the requirements of society. Thus, first of all, in society, it is necessary to form a habit of using VietGAP vegetables instead of ordinary ones with unclear origin and quality. 
Table 11. Mean of observed subjective norms variables.

\begin{tabular}{ll}
\hline Variables & Mean \\
\hline I see people around me using VietGAP vegetables & 3.7599 \\
My friends advise me to buy VietGAP vegetables & 3.7551 \\
My family would like us to include VietGAP vegetables & 3.7425 \\
\hline in our meals & \\
\hline
\end{tabular}

"My family would like us to include VietGAP vegetables in our meals" with mean $=3.7425$ indicates that not many families use VietGAP in their family meals. To do this, social media activities must be carried out regularly. Here, it is possible to invite nutritionists and housewives to use this product regularly so consumers can see the consumption trends or the social demands of consuming VietGAP vegetables.

"My friend advised me to buy VietGAP vegetables" has the mean of 3.7551. In order to improve the use of VietGAP vegetables, businesses can carry out product reviews on these products by consumers who are frequent shoppers. Consumers will introduce this standard of vegetables to their relatives, friends and co-workers to get good health. That will make consumers see their friends and people around them use VietGAP.

The observed variable "I see people around me using VietGAP vegetables" has the mean of 3.7599. Recently, with the fact that social networks are growing and most people have their own accounts, businesses can create a separate Facebook page that connects their customers together and encourages customers to join the site to like the news about health, quality, nutrition content, ... of VietGAP vegetables and share these articles with friends as well as share their attitude when using the product. This will allow other consumers to know the information about VietGAP.

According to the result, all 3 observed variables of the subjective norms had means more than 3.7, indicating that there were not many families using VietGAP vegetables in the family meals. Social media activities should be done regularly: inviting nutritionists and housewives to regularly use VietGAP products. Businesses can offer product evaluation programs to consumers who are the patrons of the stores, encourage consumers to recommend their relatives, friends and co-workers to use them. Businesses can create a social network like Facebook to connect customers, encourage customers to participate in health news, nutritional content and quality... of VietGAP vegetables, share these articles to friends as well as share their attitude towards these issues...

\subsubsection{Attitude}

Table 12. Mean of observed attitudinal variables.

\begin{tabular}{ll}
\hline Variables & Mean \\
\hline I think buying VietGAP vegetables is reasonable & 3.4455 \\
I think buying VietGAP vegetables is very clever & 3.4660 \\
I think buying VietGAP vegetables is very beneficial & 3.4550 \\
I am satisfied when buying VietGAP & 3.4139 \\
\hline
\end{tabular}

In the 4 observed variables of the attitude factor, the observed variable "I am satisfied when buying VietGAP" has the lowest average value (mean $=3.4139$ ), the highest is "I think buying VietGAP vegetables is very clever" with an average value of 3.4660 , the second highest average value $($ mean $=3.4550)$ is the variable" I think buying VietGAP vegetables is very beneficial ", the third highest average value (mean $=3.4455)$ is the variable "I think buying VietGAP vegetable is reasonable".

Consumers are happy to buy VietGAP vegetables because VietGAP vegetables ensure their health and their family members, contains many nutrients, reducing the risk of food poisoning due to the chemical content, the remaining micro in vegetables at the acceptable rate. Therefore, businesses dealing in this type of product need to introduce its benefits to consumers through the organization of programs such as agricultural fairs, nutrition seminars to create opportunities for meeting the producers, distribution companies, nutritionists and consumers, thereby increasing the level of awareness of consumers about VietGAP vegetables and that is also the trend of green consumption that society is looking forward to. Ensure that the products you sell to consumers are really safe, healthily benefical for consumers.

According to the surveyed consumers, buying VietGAP vegetables is beneficial because they contain many nutrients, the amount of residue of chemicals and microorganisms at the threshold which is acceptable for health and mentally beneficial as they feel no worry about hygiene and food safety when buying vegetables - an indispensable food in every meal. Therefore, in order to increase the attitude towards the benefits of VietGAP vegetables, VietGAP businesses must always ensure that the product is safe from cultivation and is cared until it is sold in the market. At the same time, to ensure the origin, VietGAP distributors must cooperate with producers to ensure the production process of VietGAP vegetables in accordance with the set standards; The authorities should regularly monitor, support and inspect this process. When consumers are aware of the benefits of VietGAP vegetables, the level of reasonable attitude when buying VietGAP vegetable will also increase.

The 4 observed variables of the attitude factor had means over 3.4; therefore, it came to the conclusion that consumers were not quite happy with these types of products. Businesses of these types of products need to introduce theirs benefits to consumers by organizing programs such as agricultural fairs and nutrition seminars to provide opportunities for manufacturers, distribution businesses, nutritionists, consumers. Consequensly, it can raise consumers' awareness of VietGAP vegetables and also becomes a part of the green consuming trends that society has aimed at. The products used to be sold to consumers have to be really safe and bring health benefits for sure. In addition, it should be also the effort and commitment of the manufacturers, distributors and the competent authorities.

\subsection{Limitations of Research and Proposed Further Research Trends}

Although the research objectives have been addressed, there are some limitations left as follows: (1) There are 
certainly many other factors affecting the purchase attitude have not been mentioned in this piece of research, (2) The research had been carried out only in some urban districts of HoChiMinh city; therefore, the results might not have been highly represented. (3) Some main consumption channels of VietGAP in HCMC such as hotels, restaurants, catering companies were not surveyed in this research yet. This is also considered a suggested trend for the further research.

\section{References}

[1] Ajzen I. (1985), Behavioral interventions based on the theory of planed behavior. Berlin: Springer-Verlag.

[2] Ajzen I. (1991), The theory of planned behaviour, Organizational behaviour and human decision processes, 50, pp. 179-211.

[3] Ajzen, I. (1989), Attitude Structure and Behavior. In Breckler, S. J. and Greenwald, A. G., Eds., Attitude Structure and Function, Lawrence Erlbaum, Hillsdale, 241-274.

[4] Anderson, J. C. \& Gerbing, D. W. (1988), Structural equation modelling in practice: A review and recommended two-step approach. Psychological Bulletin, pp. 411-423.

[5] Avitia, J.; Gil, J.; Costa-Font, M. (2011), Structural equation modelling of consumer acceptance of organic food in Spain. A: Congreso de Economía Agraria. "VIII Congreso de Economía Agraria". Madrid, pp. 1-36.

[6] Dickieson, J., Arkus, V., Wiertz, C., 2009. Factors that influence the purchase of organicfood: A study of consumer behaviour in the UK. [www.ein-herz-fuerbio.org/sites/default/files/downloads/dickiesonj arkusv.pdf] site visited on $08 / 08 / 2018$.

[7] Fishbein, M., \& Ajzen, I. (1975), Belief, attitude, intention and behaviour: An introduction to theory and research menlo park, California, Addison-Wesley publishing company Inc.

[8] Hair, J. A. (1999), Multivariate Analysis. Prentice Hall.

[9] Kline, R. (2005), Principles and practice of structural equation modelling. New York: The Guilford Press.

[10] Lada, S., Tanakinjal, G. H. \& Amin, H. (2009), Predicting intention to choose halal products using theory of reasoned action, International Journal of Islamic and Middle Eastern Finance and Management, 2 (1), pp. 66-76.

[11] Le, Thuy Huong (2014), The factors affecting purchase intention of clean food of urban citizens- survey in Hanoi City, $\mathrm{PhD}$ dissertation, National Economics University.

[12] Lea, E. \& A. Worsley (2008), Australian consumers' foodrelated environmental beliefs and behaviours, Appetite, 50 (2), pp. 207-214.
[13] Magnusson, M. K., Avrola, A., Hursti Koivisto, U. K., Aberg, L., Sjoden, P. O., (2003). Choice of Organic Foods is related to Perceived Consequences for Human Health and to Environmentally Friendly Behaviour, Appetite, 40, pp. 109117.

[14] Nguyen, Phong Tuan (2011), A comparative study of the intention to buy organic food between consumers in northern and southern Vietnam. AU-GSB e-Journal, 4 (2).

[15] Nguyen, Thanh Huong (2012), Key factors affecting consumer purchase intention - A study of safe vegetable in Ho Chi Minh City, Vietnam, Master of business (Honours), International School of Business, University of Economics, Ho Chi Minh City.

[16] Pham, Thi Hong Dao (2014), Factors affecting the purchase intention of safe vegetables of the consumers in Ho Chi Minh City, Master's thesis, The University of Economics Hochiminh City.

[17] Roddy, G., Cowan, C. A. and Hutchinson, G. (1996), Consumer attitudes and behavior to organic foods in Ireland, Journal of International Consumer Marketing, 9 (2), pp. 4163.

[18] Shaharudin, M. R., Pani, J. J., Mansor, S. W., Elias, S. J. (2010), Factors Affecting Purchase Intention of Organic Food in Malaysia's Kedah State, Cross-Cultural Communication, 6 (2), 105-116.

[19] Tarkiainen, A. \& Sundqvist, S. (2005), Subjective norms, attitudes and intentions of Finnish consumers in buying organic food, British Food Journal, 107 (11), pp. 808-822.

[20] Voon, J. P., Ngui, K. S., \& Agrawal, A. (2011), Determinants of willingness to purchase organic food: An exploratory study using structural equation modeling, International Food and Agribusiness Management Review, 14, pp. 103-120.

\section{Biography}

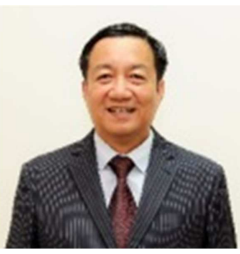

Ha Nam Khanh Giao: Associate Professor Doctor, Interest research: service, marketing, international business Assoc. Prof. PhD Ha Nam Khanh Giao is Dean of the Faculty of Air Transport, Vietnam Aviation Academy, Vietnam nowadays. He used to be Director of The Institute of Applied Economics, Head of the Faculty of Post Graduates Study, Dean of the Faculty of Tourism and Hospitality, University of Finance and Marketing, Vietnam. He supervised successfully 4 doctors and more than 200 masters. He is reviewer of 12 journals, and published more than 150 articles in the scientific journals. His research fiels are marketing, international business, services management, human resources management, tourism and hospitality. 